\title{
THE LIFE-TIME CONCEPT AS A TOOL FOR EROSION TOLERANCE DEFINITION ${ }^{1}$
}

\author{
G. SPAROVEK ${ }^{2}$; M.M. WEILL ${ }^{2,5}$; S.B.L RANIERI ${ }^{2,6}$; E. SCHNUG ${ }^{3}$, E.F. SILVA ${ }^{4}$ \\ ${ }^{7}$ Soil Science Department ESALQ/USP, C.P. 9, CEP: 13418-900 - Piracicaba, SP (Brazil). \\ ${ }^{3}$ Institute of PLant Nutrition and Soil Science (FAL), Bunderalle 50, D-38116 - Braunschweig (Germany). \\ 'Soil Reserch Center, EMBRAPA, Rua Jardim Botanico, 1024, CEP: 22460-900 - Rio de Janeiro, RJ (Brazil). \\ SSponsored by CNPq. \\ Sponsored by FAPESP.
}

\begin{abstract}
By definition, erosion tolerance should consider the conservation of the soll as a natural resource essential for crop production. Erosion rates greater than soil renewal will cause soil depth loss. A minimum soil depth was defined as the depth in which the inputs (fertilizers, crop residues) and management technology (irrigation, improved genetic crop quality) were insufiticient to prevent economic productivity loss. Thus, erosion rates greater than soll formation are acceptable only during the time in which the soll does not reach the minimum depth. We have defined this time period as life-time. The life-time concept was applied to the Ceveiro watershed (1,945 ha) located in a sugarcane growing region in the Southeast of Brazil. Erosion rates were estimated with the Universal Soll Loss Equation and soll depths were measured by field surveys. Depth change and life-time calculations, considering a soll formation rate of $0.2 \mathrm{~mm} \mathrm{y}^{-1}$, and assuming the present scenario of land use and a minimum soll depth of $1.0 \mathrm{~m}$ were made using the Geographic Information System. Land use represented 1,319 ha (68\%) of sugarcane, $346 \mathrm{ha} \mathrm{(18 \% )}$ of forests and $278 \mathrm{ha}(14 \%)$ of pasture. The area in which soll erosion was less than soll formation (not associated to long term impacts) represented 475 ha $(24 \%)$, which included the total forest areas and $48 \%$ of pastures. The total sugarcane area had erosion rates greater than soll formation. The area with erosion rates greater than soll formation rates and soil depth less than $1.0 \mathrm{~m}$, which resulted in a life-time equal to zero (soil erosion impacts are presently irreversible) was 832 ha (42\%). This area was composed of 702 ha of sugarcane and 130 ha of pastures. The remaining area (ercion greater than formation and soll depth $>1.0 \mathrm{~m}$ ) represented $638 \mathrm{ha}(32 \%)$, which was composed of 620 ha of sugarcane and $18 \mathrm{ha}$ of pasture. The half-Hifetime for the watershed was estimated as $350 \mathrm{yr}$. The life-time concept was effective to evaluate the extreme soll degradation risk of the Ceveiro watershed in an integral and reliable form.
\end{abstract}

Key Words: Erosion tolerance, life-time

\section{O CONCEITO DE TEMPO-DE-VIDA COMO FERRAMENTA PARA A DEFINIÇĀO DA TOLERÂNCIA DE PERDA DE TERRA POR EROSÃo}

\begin{abstract}
RESUMO: Por definiç̧̄o, a tolerância de perda de terra por erosão deve considerar a preservaçāo do solo como um recurso natural essencial para a produção das culturas. Taxas de erosão do solo superiores a sua renovação ocasionam diminuiçẫo da sua espessura. Uma espessura minima fol definida como sendo a espessura abaixo da qual os insumos (fertilizantes, residuos de culturas) e a tecnologia de manejo (irrigação, culturas geneticamente melhoradas) são insuficientes para manter economicamente a produtividade. Assim, taras de erosão maiores do que a formação podem ser aceitas somente durante o tempo no qual não foi atingida a espessura minima. Este periodo foi definido como tempo-de-vida. O conceito de tempo-de-vida foi aplicado na bacia do Ceveiro (1.945 ha), localizada em Piracicaba no sudeste do Brasil. O cálculo do tempo de vida foi realizado usando Sistema de Informaçōes Geográficas. Para isto foram utlizadas estimativas das taras de erosão pela Equação Universal de Perda de Solo e das profundidades do solo obtidas em levantamento de campo. Foram consideradas ainda uma tara de formaçāo de $0,2 \mathrm{~mm}$ ano ${ }^{-1}$, uma profundidade minima do solo de $1,0 \mathrm{~m}$, e o cenário atual de uso da terra. $O$ uso da terra se distribuj em 1.319 ha (68\%) de cana-de-açúcar, 346 ha (18\%) de norestas e 278 ha (14\%) de pastagens. A área na qual a erosão foi menor do que a formaçāo (área nāo associada a impactos irreversíveis) representou 475 ha (24\%). Esta área inclui o total de forestas, $48 \%$ das pastagens e nenhuma área de cana-de-açúcar. A área com taxas de erosão maiores do que a formaçāo e profundidade do solo menor que $1,0 \mathrm{~m}$, representou $832 \mathrm{ha}(42 \%)$, nos quais o tempo de-vida é Igual a zero (impactos irreversíveis da erosão no tempo atual). $O$ uso da terra nesta situaçāo se compōe de 702 ha de cana-de-açúcar e 130 ha de pastagens. Para a área restante de 638 ha (32\% da bacia) onde a erosão é maior do que formaçāo e profundidade do solo é maior do que $1,0 \mathrm{~m}$, fol estimado o tempo necessário para que $50 \%$ da área
\end{abstract}

\footnotetext{
${ }^{T}$ Research project sponsored by FAPESP
} 
atingisse a profundidade minima do solo. Este tempo, definido como meta-vida, fol estimado em 350 anos, sendo que nesta situagho se enquad ram 620 ha de cana-de-agticar e 15 ha de pastagem. $O$ concelto de tempo-de-vida mostrou-se efictente na avaliaglio de maneira integral e confivivel do riaco extremo de degradaçio da Mierobacia Hidrogrifica do Ceveiro.

Deserftores: Toleríncla de perda de terra por erouto, tempo-de-vida

\section{INTRODUCTION}

Soil is an essential natural resource, which is available in limited quantities. Soil functions are mianly in crop production and as a filtering agent indispensable for the maintenance of water quality. In tropical agroecosystems, soil erosion is the main land degradation process, especially if land use is intense (Lal, 1990). Soil erosion can reduce crop productivity, due either to soil degradation or nutrient depletion (Larson et al., 1990). Soil erosion is also an environmental hazard. In this case, the impacts are called offfarm, while silting and pollution of water resources are the major consequences (Clark, et al., 1985).

Erosion limits have to be defined in order to keep these impacts at acceptable levels. An important step forward on this issue was made when Stamey \& Smith (1964) suggested a model emphasizing several points involved in the determination of erosion tolerance, including the concepts of permanent preservation and soil improvement as a natural resource. This considers the assumption that if any soil property is available in excess at present or in the predictable future, it is tolerable to use the excess. According to these definitions, erosion tolerance, defined in terms of fixed values, can only be accepted if it is less than soil formation. If soil erosion is greater than formation, soil depth loss will occur and will not allow the permanent preservation of the soil as a natural resource.

The objective of this study was the development of the life-time concept as a tool for the definition of erosion tolerance. The applicability of this concept was evaluated at the watershed scale (Ceveiro watershed Piracicaba, Brazil), considered the most effective scale to treat problems related to erosion impacts and control (Moldan \& Cerny, 1994).

\section{MATERIALS AND METHODS}

Erosion impacts on soil preservation as a resource for crop production was considered in this evaluation. Erosion environmental impacts were not contemplated because of the lack of quantitative data applicable to the study area.

Erosion effects on crop productivity can often be decreased by productivity increase factors (Olson et al., 1994), such as high fertilizer inputs, more suitable management technology and improvements in genetic crop quality. In an erosion simulation experiment, Sparovek (1991) demonstrated a fast crop productivity restoration under high-input agriculture for an oxisol, even after the complete removal of the topsoil $(45 \mathrm{~cm})$. Thus, under the Ceveiros watershed conditions, i.e. high input irrigated sugarcane production, it is expected that even high present erosion rates will not be associated with an immediate productivity reduction. Although high erosion rates do not assure the permanent preservation of the soil as a natural resource, once soil depth loss occurs and a minimum soil depth will be reached or the entire soil will be removed.

In order to assess long-term soil degradation, some definitions were established. Minimum soil depth was defined as the depth at which the productivity increase factors (fertilizer, irrigation, crop management, improvement of genetic crop quality) are not sufficient to prevent economic productivity loss. In similar conditions as in the Ceveiro watershed (under intense natural erosion and high input agriculture) Salviano (1996) could identify direct impacts of soil erosion on crop productivity only after the remaining soil was less than $0.8 \mathrm{~m}$. Skidmore (1982) used a similar definition for minimum soil depth and suggested the depth of $0.5 \mathrm{~m}$. Thus, erosion rates greater than soil formation are acceptable only during the time soil does not reach the minimum depth. After that almost irreversible productivity loss will occur, i.e. the available technology will not be sufficient to counterbalance the erosion impacts and soil preservation. This time was defined as life-time. When the life-time is reached, soil erosion tolerance must be equal to or less than soil formation rates.

The life-time concept was applied to the Ceveiro watershed $(1,945 \mathrm{ha})$ located in a sugarcane growing region near Piracicaba, in the 
Southeast of Brazil. Due to its proximity to industry and the possibility of irrigation with industrial residues (vinasse), the pressure of occupation with sugarcane has been great and the management intense. Degradation due to soil erosion was clearly visible through the intense silting of water reservoirs and a high frequency of gullies.

For the life-time calculations, minimum soil depth of $1.0 \mathrm{~m}$ was considered and soil formation, according to Friend (1992), was assumed to be $0.2 \mathrm{~mm} \mathrm{y}^{-1}$. Soil erosion rates in the present scenario of land use were estimated using the Universal Soil Loss Equation (USLE) (Wischmeier \& Smith, 1978) and the Geographic Information System (GIS) following the procedures described by Ranieri (1996).

Soil depths were measured by field surveys and were defined for the soil map units. The soil types classified according to the Brazilian Soil Classification System, its depths and occurrence are shown in TABLE 1.

TABLE 1 - Soil types, occurrence and depths in the Ceveiro Watershed.

\begin{tabular}{lcc}
\hline \multicolumn{1}{c}{ Soil Type } & $\begin{array}{c}\text { Depth } \\
(\mathrm{m})\end{array}$ & $\begin{array}{c}\text { Occurrence } \\
\text { (ha) }\end{array}$ \\
\hline Litossolos & 0.5 & 45.62 \\
Podzblico pouco profundo, Solos Hidromórficos, Solos Aluviais & 1.0 & 14.39 \\
Cambissolos & 1.5 & 3.75 \\
Podzólicos Vermelho-Amarelo, Terra Roxa Estruturada Podzólica & 2.0 & 7.83 \\
Podzólicos Vermelho-Amarelos, Terra Roxa Estruturada & 2.5 & 16.5 \\
Podzólicos Vermelho-Amarelos, Podzólico Vermelho-Escuro & 3.0 & 9.96 \\
\hline
\end{tabular}

The life-time calculations assumed that the present scenario that is, the management and conservation practices and crops would continue into the future.

The selected $\mathbf{C}$ factors from the USLE for the different land use types and its occurrence are shown in TABLE 2.

TABLE 2 - Land use types and occurrence and Universal Soil Loss Equation C factor in the Ceveiro Watershed

\begin{tabular}{ccc}
\hline Land use type & $\mathbf{C}$ factor & $\begin{array}{c}\text { Occurrence } \\
(\%)\end{array}$ \\
\hline Sugarcane & 0.11 & 66.3 \\
Pasture & 0.008 & 13.9 \\
Annual Crops & 0.55 & 0.2 \\
Forests & 0.0001 & 17.3 \\
Other uses & & 2.3 \\
\hline
\end{tabular}

\section{RESULTS AND DISCUSSION}

Land use type, soil depth, erosion rate and half-time distribution were calculated (Figures 1a, 1b, 1c and 1d).
The area in which soil erosion was less than soil formation represented 475 ha (24\% of the total). According to the definitions, in these areas the minimum soil depth will never be reached (soil depth is increasing), and the preservation of the soil as a natural resource is assured. These areas included the total forests and $48 \%$ of the pastures. They were concentrated along the flood plains (Figure 1d), presented low erosion rates (Figure 1c) and were not necessarily associated to deeper soils (Figure 1b). Flood plains also trap sediments originating from soil erosion (Foster, 1982).

Sediment tapping, a soil depth increase process, is not considered in this paper but will also contribute to the prevention of soil depth loss. The pressure of occupation with low-lying sugarcane (flood plain positions) was low due to management restrictions. The presence of forests and pastures was another factor that contributed to the preservation of these areas. 


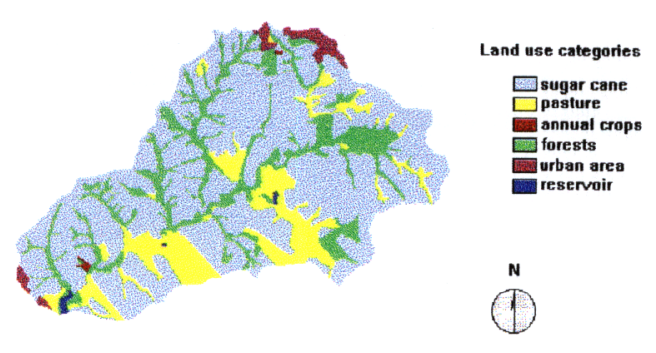

(a)
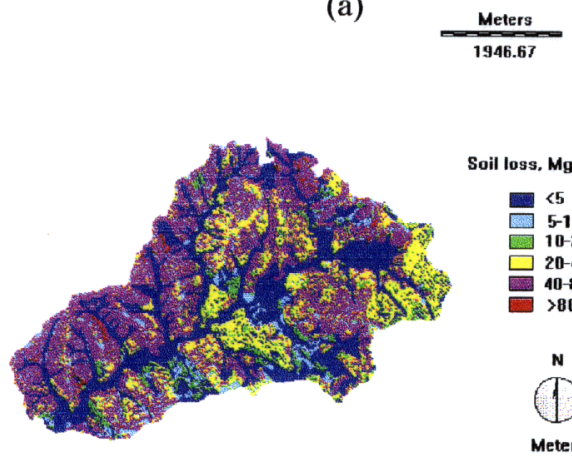

(c)

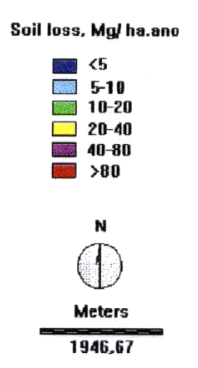

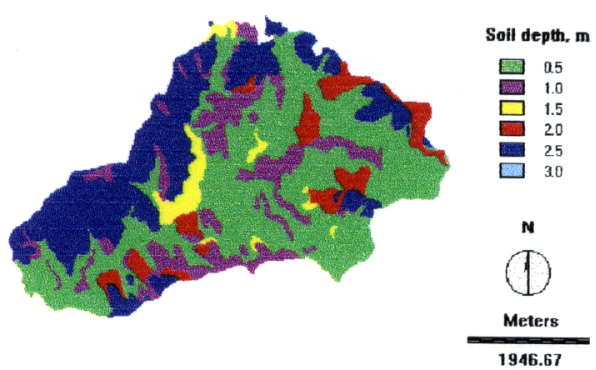

(b)

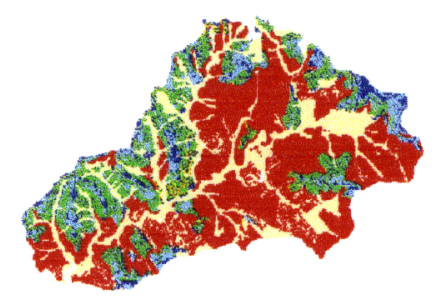

(d)

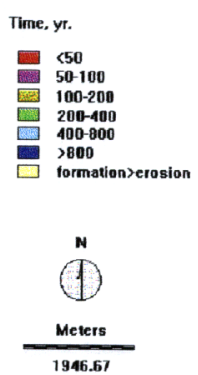

Figure 1 - (a) Land use type, (b) soil depth, (c) erosion rates and (d) half-time distribution in the Ceveiro Watershed.

The total sugarcane area had erosion rates greater than soil formation rates, consequently soil depth loss will occur. Thus, in these areas, the minimum soil depth has already been (life-time $=0$ ) or will be (life-time $>0$ ) reached. The area of sugarcane with life-time equal to zero (soil depth $<1.0 \mathrm{~m}$ and erosion > formation) was 702 ha (36\%) and areas with positive values for life-time were 617 ha (31\%). The relation between the relative area for the entire watershed and the land use types and the life-time is shown in Figure 2. Conceptually, zero life-time indicates that irreversible productivity loss is occurring at present time. The positive half-time values denote areas in which the productivity increase factors have counterbalanced erosion impacts on economic productivity loss at the present time, but soil is not preserved as a natural resource. The large relative area with life-time equal to zero and a final value of 1.0 indicated that sugarcane is the major land use conflict in this area. According to the shape of the curve (Figure 2), the present situation could be sustained for a period of 100 years before significant increase in relative area were observed. The presence of sugarcane in soils with high erosion susceptibility regionally affects $30 \%$ of these lands (Sparovek \& Lepsch, 1995). From the total pasture area of 278 ha (14\%), 133 ha demonstrated soil formation rates greater than soil erosion and 130 ha had life-time equal to zero. The remaining 15 ha presented positive half-time values. These data and the shape of the curve (Figure 2), indicated that the relative where erosion impacted productivity was great, but no significant increase can be expected for the future.

The whole watershed presented a bias similar to that observed for sugarcane, its major land use. The relative area with life-time equal to zero was 0.43 , which increased to a maximum of 0.76 . Therefore. only $24 \%$ of the soils are preserved as natural resource. The half-life-time for the watershed (the time needed for $50 \%$ of the 
area with erosion greater than soil formation to reach the minimum soil depth) was 350 years. The present irreversible degradation should remain stable for approximately 100 years, after which, the relative area at the minimum soil depth will increase significantly and erosion tolerance will need to decrease in order to assure productivity preservation.

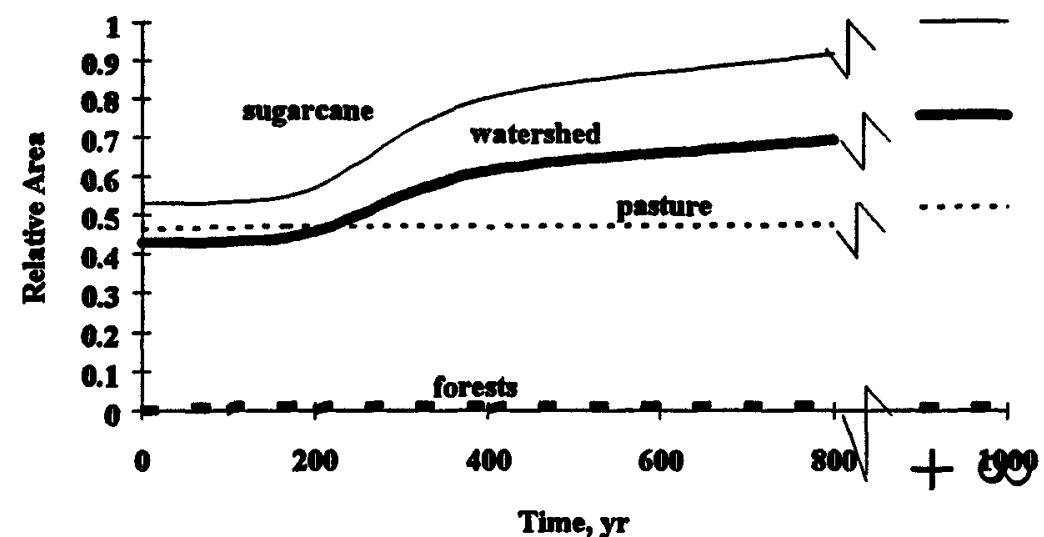

Figure 2 - Relative area for the whole watershed and the associated land use types in relation to the lifetime in the Ceveiro Watershed.

The life-time concept allowed a precise definition of erosion tolerance, while indicating land use conflicts, emphasized the need and time of interference according to the land use type. The long-term consequences of current management technologies and land use types, defined mostly by economical conditions, could be identified as well as its sustainability. The life-time concept allowed a low subjective land evaluation procedure (Diepen et al., 1991), treated soil information quantitatively (Bouma, 1989) and was compatible with GIS resulted more reliable results.

\section{CONCLUSTONS}

Irreversible impacts on crop productivity due to soil erosion constitutes a serious problem in the Ceveiro watershed, and this is associated with intensive cultivation of sugarcane. The present situation can be sustained for approximately 100 years, after which land degradation will increase significantly. The lifetime concept allowed reliable evaluation of the impact of soil erosion on crop productivity.

\section{REFERENCES}

BOUMA, J. Using soil survey data for quantitative land evaluation. In: STEWART, B. A, ed. Advances in Soll Science, Springer-Verlag New York Inc., v.9. p.177-213, 1989.

CLARK, E.H.; HAVERKAMP, J.A; CHAPMAN, W. Eroding Solls The off-farm impacts. Washington, D.C., The Conservation Foundation. p.1-252, 1985.

DIEPEN, C.A.; KEULEN, H.; WOLF, J.; BERKHOUT, J.A.A. Land evaluation: from intuition to quantification. Advances in Soll Science, v.15, p.139-204, 1991.

FOSTER G.R. Modeling the erosion process. In: HAAN, C.T; JOHNSON, H.P.; BRAKENSIEK, D.L., eds. Hydrologic modeling of small wateraheds. St. Joseph: ASAE, p.294-380, 1982.

FRIEND, J.A. Achieving soil sustainability. Journal of Soll and Water Conservation, v.47, p.156-157, 1992.

LAL; R. Soil erosion and land degradation: the global risks. Advances in Soll Sclence, v.7, p.129-172, 1990. 
LARSON, W.E.; FOSTER, G.R.; ALMARAS, R.R; SMITH, C.M., eds. Proceedings of soll erosion and productivity workshop. Minessota, 142p., 1990.

MOLDAN, B.; CERNY, J. Biogeochemistry of mall catchments. A tool for environmental research. Chichester: John Wiley \& Sons. p.1-419, 1994.

OLSON, K.R.; LAL, R.; NORTON, L.D. Evaluation of the methods to study soil erosion-productivity relationships. Journal of the Soll and Water Cons. v.49, p.586-590, 1994.

RANIERI, S.B.L. Avaliaçào de métodos e escalas de trabalho para determinagăo de risco de erosăo $\mathrm{em}$ bacia hidrografica utilizando SIG. Sto Carlos, SP, 1996. 128p. (Dissertacia) Mestrado - Escola de Engenharia de Sz̃o Carlos, Universidade de Săo Paulo.

SALVIANO, A.C. Relaçóes entre atributos de solo e produtividade da Crotalaria juncea em área erodida. Piracicaba, SP, 1996. 92p. (Tese) Doutorado - Escola Superior de Agricultura Luiz de Queiroz, Universidade de Săo Paulo.

SKIDMORE, E.L. Soil-loss tolerance. In: American Society of Agronomy. Determinnnts of soll loss tolerance. p.87-93, 1982.
SPAROVEK, G.; TERAMOTO, E.R.; TORETA, D.M.; ROCHELE, T.C.P.; SHAYER, E.P.M. Erosa simulada a produtividade da cultura do milho. Revista Brastleira de Clência do Solo, v.15, p.363-368, 1991.

SPAROVEK, G; LEPSCH, I.F. Diagnóstico de uso e aptidão das terras agricolas de Piracicaba. In: TAUKTORNISIETO, S.M.; GOBEI, N.; FORESTI, C.; LIMA, S.T. DE. Andilive amblental: estrategins e açies. Săo Paulo: Queiroz, p. 273-9, 1995.

STAMEY, $\mathbf{W}$. L; SMITH, R. M. A conservation definition of erosion tolerance. Soll Science, Baltimore, v.97, p.183-6, 1964.

WISCHMEIER, W. H.; SMITH, D. D. Predicting roinfall erosion losses $-A$ guide to conservation planning. U.S. Department of Agriculture, Sci. and Educ. Admin., Agriculture Handbook., 537, 1978.
Recebido para publicagåo em 12.05 .97 Aceito para publicagäo em 18.05 .97 